\title{
MENUMBUHKAN SIKAP SOPAN SANTUN DALAM KEHIDUPAN SEHARI - HARI MELALUI LAYANAN KLASIKAL BIMBINGAN DAN KONSELING KELAS XI SMA NEGERI 3 SUKADANA
}

\author{
Hesti Pertiwi \\ SMA Negeri 3 Sukadana
}

\begin{abstract}
ABSTRAK
Sopan santun adalah suatu sikap, tingkah laku atau perbuatan yang dilakukan individu untuk menghormati dan menghargai orang lain di sekitarnya. Tujuan penelitian ini ada tiga, yaitu: 1) untuk memahami sikap sopan santun, 2) untuk menganalisis pentingnya perilaku sopan santun, 3) Untuk memprediksi dampak tidak berperilaku sopan santun. Jenis penelitian ini adalah kualitatif dengan desain deskriptif. Subjek penelitian adalah siswa kelas XI SMA Negeri 3 Sukadana. Teknik pengumpulan data dilakukan dengan observasi, wawancara semi terstruktur, dan dokumentasi. Teknik analisis data menggunakan reduksi data, penyajian data, dan penarikan kesimpulan. Hasil penelitian menunjukkan bahwa: 1) Metode pembinaan etika sopan santun dilakukan melalui tiga cara yaitu metode demonstrasi, ceramah, dan pembelajaran berbasis proyek; 2) kendala yang dihadapi guru adalah karakter siswa yang berbeda dan berubah-ubah karena usia siswa masih labil, 3) upaya yang dilakukan dalam menmgatasi kendala adalah dengan bekerjasama antara pihak sekolah, keluarga, maupun masyarakat.
\end{abstract}

Kata Kunci: sopan santun, layanan klasikal, bimbingan dan konseling

\section{PENDAHULUAN}

Pendidikan merupakan proses perubahan sikap dan perilaku individu atau kelompok melalui upaya belajar, pengajaran, dan pelatihan untuk mencapai tujuan tertentu. Menurut UU No. 20 Tahun 2003 pasal 1 menyatakan bahwa pendidikan adalah usaha sadar dan terencana untuk mewujudkan suasana belajar dan proses pembelajaran agar peserta didik secara aktif mengembangkan potensi dirinya untuk memiliki kekuatan spiritual keagamaan, pengendalian diri, kepribadian, kecerdasan, akhlak mulia, serta keterampilan yang diperlukan dirinya, masyarakat, bangsa, dan negara.

Fitri Puji Rahmawati, dkk (2014: 110) mengatakan bahwa pendidikan karakter saat ini merupakan bagian terpenting dari pendidikan di Indonesia ketika masyarakat setiap hari disuguhi rekaman tingkah laku masyarakat Indonesia yang jauh dari nilai-nilai karakter Indonesia yang lemah lembut, sopan, ramah, dan menjunjung tinggi budaya timur. Sehingga sarana yang paling mudah digunakan untuk mengembalikan nilai-nilai karakter yang telah terkikis dengan cara mengajarkan dan menerapkan pendidikan karakter di sekolah. Karakter identik dengan akhlak yang merupakan nilai-nilai perilaku manusia yang universal yang melipui seluruh aktivitas manusia baik yang berhubungan dengan Tuhan, dirinya sendiri, sesama manusia, dan lingkungannya terwujud dalam pikiran, perasaan, dan perkataan serta perilaku sehari-hari.

Sebagaimana diketahui, pembelajaran etika dan sopan santun di Sekolah Dasar diterapkan dengan diikutsertakan pada mata elajaran PKn, pendidikan agama pengembangan diri, Bimbingan dan Konseling juga terlibat di dalamnya.

Perilaku sopan santun adalah peraturan hidup yang timbul dari hasil 
Jurnal Inovasi BK,Volume 2, Nomor 2 Desember 2020 pergaulan sekelompok manusia di dalam masyarakat dan dianggap sebagai tuntunan pergaulan sehari-hari masyarakat itu. Perilaku sopan santun merupakan unsur penting dalam kehidupan bersosialisasi sehari-hari setiap orang, karena dengan menunjukkan sikap sopan santunlah, seseorang dapat dihargai dan disenangi dengan dengan keberadaannya sebagai makhluk sosial dimana pun tempat ia berada.

Mengacu pada pengertian sopan santun daalam proses pembelajaran di kelas, maka diperlukan pengembangan pembelajaran agar siswa dapat memahami pesan-pesan etika sopan santun melalui layanan Bimbingan dan $\mathrm{K}$ onseling yaitu layanan klasikal. Dalam panduan Bimbingan dan Konseling yang dikeluarkan Direktorat Jendral Peningkatan Mutu Pendidikan dan Tenaga Kependidikan Departemen Pendidikan Nasional ( 2007 ) layanan klasikal merupakan salah satu layanan dasar bimbingan yang dirancang menuntut konselor melakukan kontak langsung dengan siswa secara terjadwal, berupa kegiatan diskusi kelas, tanya jawab, dan praktik secara langsung yang dapat membuat siswa aktif dan kreatif dalam mengikuti kegiatan yang diberikan. Tujuan penelitian ini ada tiga, yaitu: 1) untuk memahami sikap sopan santun, 2) untuk menganalisis pentingnya perilaku sopan santun, 3) Untuk memprediksi dampak tidak berperilaku sopan santun

\section{METODE}

Jenis penelitian ini adalah kualitatif dengan desain deskriptif. Subjek penelitian adalah siswa kelas XI SD SMA Negeri 3 Sukadana. Sedangkan sampel menggunakan sampel jenuh, dimana seluruh populasi dijadikan sebagai sampel dalam penelitian ini yaitu 42 siswa. Teknik pengumpulan data dilakukan dengan observasi, wawancara semi terstruktur, dan dokumentasi. Teknik analisis data menggunakan reduksi data, penyajian data, dan penarikan kesimpulan

\section{HASIL DAN PEMBAHASAN}

Metode yang digunakan pada saat layanan klasikal sopan santun menggunakan metode pembelajaran yang mudah di terapkan kepada siswa. Mengacu pada Mulyasa (2013: 165) dalam penelitian Muhammad Ali bahwa beberapa model yang dapat diterapkan pada pendidikan karakter antara lain: pembiasaan dan keteladanan, pembinaan disiplin, hadiah dan hukuman, CTL (contextual teaching and learning), bermain peran (role playing), dan pembelajaran partisipatif (participative instruction).

Metode yang digunakan yaitu metode ceramah, demonstrasi, dan pembelajaran berbasis proyek. Dengan menggunakan metode ceramah dan metode demonstrasi siswa belum mampu memahami materi pembelajaran yang sedang berlangsung. Metode bermain peran (role play) merupakan metode yang sesuai jika digunakan untuk siswa kelas I dengan peristiwa yang benar-benar nyata terjadi dan di perankan oleh siswa itu sendiri yang kemudian siswa akan memperoleh informasi berdasarkan apa yang di lihat oleh siswa.

Metode bermain peran (role play) mampu membangun keaktifan siswa selama pelaksanaan pembelajaran karena siswa terlibat langsung dalam pembelajaran yang menjadikan siswa sebagai tokoh utama pembelajaran karena lebih berperan aktif selama mengikuti pembelajaran, dan guru hanya sebagai fasilitator pembelajaran untuk mewujudkan pembelajaran yang menyenangkan. Hal tersebut diperkuat oleh pendapat Akhmad Sutrajad (2013:6) karakteristik pembelajaran tematik antara lain: (1) berpusat pada siswa, (2) memberikan pengalaman langsung (direct experience), (3) pemisah mata pelajaran tidak begitu jelas, (4) menyajikan konsep dari beberapa mata pelajaran, (5) bersifat 
fleksibel, dan (6) menggunakan prinsip belajar sambil bermain dan menyenangkan. Pembelajaran berbasis proyek adalah metode pembelajaran yang menggunakan proyek / kegiatan sebagai media. Peserta didik melakukan eksplorasi, penilaian, interpretasi, sintesis, dan informasi untuk menghasilkan berbagai bentuk hasil belajar.

Hasil penelitian di atas sejalan dengan penelitian yang dilakukan oleh Kurniawati, dkk (2016) yang menyatakan bahwa peranan guru sebagai inspirator dalam menanamkan perilaku sopan santun pada anak guru selalu berupaya menunjukkan perilaku sopan santun pada anak dengan menujukkan perilaku sopan santun dirinya didepan anak. Peranan guru sebagai model dalam menanamkan perilaku sopan santun pada siswa, guru selalu berupaya untuk menunjukan contoh-contoh yang baik kepada siswa dan guru berusaha untuk bersikap sopan santun di depan anakanak. Peranan guru sebagai motivator dalam menanamkan perilaku sopan santun pada anak guru selalu memotivasi atau mendorong siswa untuk lebih baik dengan memberikan pujian atau reword kepada siswa yang perilaku sopan santunya baik dan guru memotivasi siswa yang perilaku sopan santunya kurang baik dengan cara memberikan penjelasaan dan nasehat.

Berdasarkan hasil penelitian diperoleh hasil bahwa metode yang digunakan pada layanan klasikal sopan santun yaitu dengan menggunakan metode ceramah, metode demonstrasi, dan metode bermain peran (role play), dan pembelajaran berbasis proyek karena siswa dapat berperan aktif dalam setiap kegiatan pembelajaran dan kelas tersebut akan lebih terasa hidup sehingga menciptakan suatu pembelajaran yang menyenangkan bagi siswa.

Berlangsungnya pembelajaran harus diperhatikan oleh guru mengenai bagaimana menciptakan suasana belajar yang nyaman dan menyenangkan bagi siswa, untuk itu pemilihan metode pembelajaran harus tepat dan sesuai dengan memperhatikan langkah-langkah pelaksanaan metode pembelajaran bermain peran (role play) tersebut. Langkah-langkah bermain peran (role play) menurut Hamzah (2010: 27) terdiri atas sembilan langkah antara lain: pemanasan (warming up), (2) memilih pemain (partisipan), (3) menata panggung, (4) menyiapkan pengamat (observer), (5) permainan dimulai, (6) evaluasi, (7) permainan peran ulang, (8) pembahasan diskusi dan evaluasi lebih diarahkan pada realitas, dan (9) kesimpulan. Upaya yang dilakukan oleh guru Bimbingan dan Konseling dalam menanamkan karakter sopan santun pada siswa juga menggunakan pembelajaran berbasis proyek dengan langkah - langkah 1 ) menentukan petanyaan dasar, 2 ) membuat desain proyek, 3) menyusun penjadwalan, 4 )memonitor penjadwalan proyek, 5 ) penilaian hasil, 6 ) evaluasi

Berdasarkan hasil penelitian diperoleh hasil bahwa pelaksanaan layanan klasikal sopan santun dapat berjalan dengan baik, siswa mampu memainkan cerita bersama kelompoknya dan siswa terlibat secara langsung selama pembelajaran yang dapat membangun keaktifan siswa di kelas yang menjadikan suasana kelas menjadi lebih hidup, aktif, dan menyenangkan sehingga tidak membuat siswa merasa cepat bosan karena menerapkan prinsip belajar sambil bermain yang menyenangkan sesuai dengan karakter siswa. .

Dalam pelaksanaan layanan klasikal sopan santun di kelas XI SMA Negeri 3 Sukadana terdapat kendala/hambatan yang mempengaruhi pelaksanaan pembinaan etika sopan santun di kelas I, diantaranya yaitu, hambatan terletak pada siswa yang terkadang sulit dikendalikan, dan setelah siswa kembali ke lingkungannya, maka etika sopan santun yang ditanamkan di sekolah mudah hilang. Siswa sepenuhnya 
Jurnal Inovasi BK, Volume 2, Nomor 2 Desember 2020 belum mampu memainkan perannya sesuai naskah cerita dengan tepat sehingga guru masih mendampingi siswa.

Upaya yang dapat dilakukan dalam mengatasi kendala/hambatan saat menanamkan karakter sopan santun melalui pembelajaran secara umum dalah dengan melakukan kerjasama antara pihak sekolah, keluarga dan masyarakat. Hal ini diwujudkan dengan saling memberikan masukan apabila ditemukan siswa melanggar etika, maka guru menyampaikan kepada orang tua siswa demikian sebaliknya orang tua harus berlapang dada dalam menerima masukan dari pihak sekolah. Secara khusus, guru memberikan contoh perilaku sopan santun yang nyata dimulai dari perilaku-perilaku kecil guru seperti datang ke sekolah tepat waktu, berkomunikasi antar sesama guru dengan baik, dalam penerapan pembelajaran lebih banyak menggunakan metode bermain peran.

\section{KESIMPULAN}

Pelaksanaan layanan klasikal sopan santun di SMA Negeri 3 Sukadana dilakukan dengan metode ceramah, demonstrasi,bermain peran (role play) dan pembelajaran berbasis proyek melalui keteladanan, pembiasaan, dan bermain peran sebagai contoh perilaku etika sopan santun yang nyata dan mampu meningkatkan perilaku sopan santun siswa dalam berkomunikasi dengan sesama.

Hambatan dalam pelaksanaan pembinaan etika sopan santun yaitu karakteristik siswa yang berbeda dengan siswa lainnya, kemampuan masing-masing siswa yang berbeda-beda, kurangnya pemahaman siswa tentang perilaku sopan santun, dan kurangnya penanaman sopan santun di lingkungan keluarga yang berperan penting dalam perkembangan siswa.

Upaya dalam mengatasi permasalahan sopan santun yaitu dengan menciptakan hubungan kerja sama saling terbuka antara pihak sekolah, keluarga, dan masyarakat untuk melakukan pembinaan dan pengawasan terhadap perilaku sopan santun siswa, dan program pembinaan etika sopan santun di sekolah lebih ditingkatkan supaya dapat membentuk perilaku etika sopan santun yang kuat di dalam diri siswa yang akan mempengaruhi perilaku siswa sehari-hari.

\section{DAFTAR PUSTAKA}

Akbar, Sa'dun, dkk. (2016). Implementasi Pembelajaran Tematik Sekolah Dasar. Bandung: PT. Remaja Rosdakarya.

Ibrahim, Hakki, O. (2011). Curriculum Reform and Teacher Autonomy in Turkey: The Case of The History Teaching., 4 (2). 1694-609X. Diakses melalui https://eric.ed.gov/?id=ED522675 pada tanggal 24 Oktober 2018. Jurnal Internasional.

Kadir, Abdul, Hanun, Asrohah. (2014). Pembelajaran Tematik. Depok: PT. Rajagrafinda Persada.

Rahmawati, Puji, F, dkk. (2014). Implementasi Model Pembelajaran "Berkah Anang" di Kalangan Siswa Pendidikan Dasar Berbudaya Jawa, Vol. 1, No. 2. Jurnal Pendidikan.

Diakses melalui https://publikasiilmiah.ums.ac.id/bit stream/handle/11617/5225/3.pdf?se quen $\quad \mathrm{ce}=1 \&$ isAllowed $=\mathrm{y}$ pada tanggal 14 April 2019.

Rusman. (2015). Pembelajaran Tematik Terpadu Teori Praktik dan Penilaian. Depok: PT. Rajagrafindo Persada.

Rusmini. (2012). Peran Guru Dalam Menanamkan Karakter Sopan Santun Siswa. Jurnal Pendidikan. Diakses melalui http://id.portalgaruda.org/index.php? ref $=$ browse \&mod=viewarticle\&artic $1 \mathrm{e}=96057$ pada tanggal 13 April 2019. Jurnal Nasional. 
Sri, Jatien, Nandang. ( 2015). Peran Orang Tua Dalam Pembentukan Kakater Pada Siswa SD Muhammadiyah Tegalgede Karanganyar. Diakses melalui

http://eprints.ums.ac.id/33569/10/N ASKAH\%20PUBLIKASI.pdf pada tanggal 13 April 2019. 